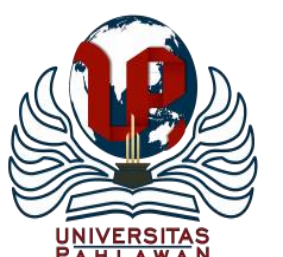

Jurnal Abdidas Volume 1 Nomor 2 Tahun 2020 Halaman 38- 42

JURNAL ABDIDAS

Community Development Service on Educational and Health Sciences http://abdidas.org/index.php/abdidas

\title{
PELATIHAN PENGUKURAN KINERJA ORGANISASI KEMASYARAKATAN DALAM MENINGKATKAN TATAKELOLA PKK
}

\author{
Ludwina Harahap \\ Universitas Trilogi, DKI Jakarta, Indonesia \\ e-mail : ludyhara@trilogi.ac.id
}

\begin{abstract}
Abstrak
Pengukuran kinerja diperlukan untuk mengetahui sampai sejauh mana tujuan organisasi; yang diturunkan dari visi misi; dapat dicapai. Melalui pengukuran kinerja dapat dilihat apakah kegiatan yang dilaksanakan sesuai dengan perencanaan, ketentuan, aturan dan didukung oleh tata administrasi yang baik. Pengukuran kinerja tidak sekedar mengukur apa yang telah dilakukan. Pengukuran kinerja dapat menjadi alat yang berfungsi untuk meningkatkan kinerja melalui perbaikan organisasi terus menerus (sustainability), namun sayangnya pengukuran kinerja belum dirasakan sebagai suatu alat yang dapat difungsikan secara optimal dalam meningkatkan kinerja organisasi secara berkesinambungan. Pelatihan pengukuran kinerja didasarkan oleh kondisi dimana penulis melihat beberapa organisasi kemasyarakatan dijalankan oleh pengurus yang sebagian besar belum paham tujuan didirikan organisasinya. Kegiatan dilaksanakan selama ini berdasarkan rutinitas saja tanpa mengetahui apakah kegiatan yang dilaksanakan tersebut sudah on the track dalam mencapai tujuan organisasi. Apakah kegiatan yang dilakukan sudah sesuai dengan yang seharusnya dijalankan, sudah memperhatikan tatakelola organisasi yang baik (good corporate governance). Contoh sederhana, dokumentasi sebagai salah satu ukuran untuk menilai kinerja organisasi sering diabaikan oleh pengurusnya. Permasalahan tersebut dapat diperbaiki secara bertahap dengan salah satu solusi yang ditawarkan yaitu memberikan pemahaman dan pendalaman materi kepada pengurus organisasi kemasyarakatan (terutama organisasi kewanitaan PKK) melalui pelatihan Pengukuran Kinerja Organisasi Kemasyarakatan. Diharapkan dengan pemahaman yang mendalam terhadap pentingnya pengetahuan pengukuran kinerja dan pengimplementasiannya maka diharapkan tatakelola PKK akan meningkat.
\end{abstract}

Kata Kunci: pengukuran kinerja, tata kelola, good corporate governance, PKK

\begin{abstract}
Performance measurement could be best way to find out whether organizational goals which is derived from vision and mission are achieved or not. It will be seen whether the implementation of activities is in accordance with planning, regulations, and good corporate governance. Performance measurement is not just measuring what has been done, the implication is more than just a measurement. Performance measurement can be a tool that serves to improve performance through continuous organizational improvement (sustainability). However, performance measurement has not been felt as a tool that can function optimally in improving organizational performance on an ongoing basis. Performance measurement training for public or social service organization $(P K K)$ is based on the condition where almost the committee do not understand the purpose of establishing or doing an organization because so far what has been done is just as routine activities without knowing whether the activities carried out are already on the track to achieve organizational goals. Are the activities carried out in accordance with what should be carried out? Does the activity carried out pay attention to good corporate governance. As a simple example, organization documentation as one of the measures to assess organizational performance is often ignored. The problem illustrated above should be corrected gradually. One solution offered is establishing training about performance evaluation to provide much understanding and deepening of the material to the organizers of social organizations (especially the PKK women's organizations). It is hoped that after having some knowledge and deep understanding the importance of performance measurement and implementing it to their organization (PKK).
\end{abstract}

Keywords: performance evaluation, good corporate governance, PKK

Copyright (c) 2020 Ludwina Harahap

$\triangle$ Corresponding author :

Address : Universitas Trilogi Jakarta

Email : ludyhara@trilogi.ac.id

ISSN 2721-9224 (Media Cetak)

Phone : :081319434995

DOI: https://doi.org/10.31004/abdidas.v1i2.11 
39 Pelatihan Pengukuran Kinerja Organisasi Kemasyarakatan Dalam Meningkatkan Tatakelola PKK - Ludwina Harahap

DOI: https://doi.org/10.31004/abdidas.v1i2.11

\section{PENDAHULUAN}

Suatu organisasi didirikan umumnya mempunyai tujuan (goal), yaitu suatu penjabaran dari visi dan misi dan hal-hal yang ingin dicapai atau dihasilkan oleh suatu organisasi atau perusahaan. Tujuan merupakan target yang bersifat kuantitatif dan merupakan pencapaian ukuran keberhasilan kinerja suatu organisasi. Tujuan adalah hasil akhir atau segala sesuatu yang akan dicapai. Tujuan yang baik bersifat specific, measurable, action-oriented, realistic, dan timely (khusus, terukur, orientasi pada tindakan, realistis, serta ada periode/waktu).

Visi merupakan rangkaian kalimat yang menyatakan cita-cita atau impian sebuah organisasi yang ingin dicapai di masa depan (want to be). Visi dapat berupa pernyataan tentang tujuan organisasi yang diekspresikan dalam produk dan pelayanan yang ditawarkan, kebutuhan yang dapat ditanggulangi, kelompok masyarakat yang dilayani, nilai-nilai yang diperoleh serta aspirasi dan cita-cita masa depan.

Misi merupakan alasan mendasar eksistensi suatu organisasi. Pernyataan misi organisasi, terutama di tingkat unit bisnis menentukan batas dan maksud aktivitas bisnis. Jadi perumusan misi merupakan realisasi yang akan menjadikan suatu organisasi mampu menghasilkan produk dan jasa berkualitas yang memenuhi kebutuhan, keinginan dan harapan pelanggannya. Misi juga merupakan rangkaian kalimat yang menyatakan tujuan atau alasan eksistensi organisasi yang memuat apa yang disediakan oleh perusahaan kepada masyarakat, baik berupa produk ataupun jasa.

\section{Pemberdayaan Kesejahteraan Keluarga} (disingkat PKK), merupakan suatu organisasi kemasyarakatan yang mengajak para ibu/wanita untuk turut serta berpartisipasi dalam pembangunan Indonesia, terutama keluarga dan masyarakat. Sebagai suatu organisasi tentunya PKK memiliki tujuan, visi maupun misi.

Tujuan gerakan PKK memberdayakan keluarga untuk meningkatkan kesejahteraan menuju terwujudnya keluarga yang beriman dan bertaqwa kepada Tuhan Yang Maha Esa, berakhlak mulia dan berbudi luhur, sehat sejahtera, maju dan mandiri, kesetaraan dan keadilan gender serta kesadaran hukum dan lingkungan (timur.jakarta.go.id, 2020).

Visi menjadi agen perubahan mental keluarga yang positif, peduli, dan bekerja dengan hati, melalui pemenuhan kebutuhan dasar seorang manusia agar terwujud masyarakat yang berkualitas, sehat, sejahtera, maju, mandiri, bahagia dan responsif (timur.jakarta.go.id, 2020). Sedangkan misi PKK terdiri dari 7 butir sebagai berikut: 1. Menciptakan agen dan memantabkan jenjang perubahan mental keluarga untuk mendorong terciptanya kebutuhan dasar di masyarakat, serta meningkatkan pembentukan karakter keluarga melalui penghayatan pengamalan pancasila, kegotong royongan dan keadilan gender. 2. Mengembangkan program peningkatan pendidikan dan ekonomi keluarga yang tepat sasaran melalui berbagai upaya ketrampilan dan pengembangan koperasi secara terpadu dan berkelanjutan. 3. Mengembangkan program peningkatan ketahanan pangan keluarga yang tepat sasaran melalui pemenuhan pangan, sandang dan perumahan sehat layak huni secara terpadu dan berkelanjutan. 4. Mengembangkan program peningkatan derajat kesehatan keluarga, kelestarian lingkungan hidup serta perencanaan sehat secara terpadu dan berkelanjutan. 5 . Mengembangkan program peningkatan pengelolaan gerakan PKK meliputi kegiatan pengorganisasian dan peningkatan sumberdaya manusia. 6. Melaksanakan setiap program menjadi pintu masuk perubahan pola pikir, pola kerja, 
40 Pelatihan Pengukuran Kinerja Organisasi Kemasyarakatan Dalam Meningkatkan Tatakelola PKK - Ludwina Harahap

DOI: https://doi.org/10.31004/abdidas.v1i2.11

sinergi dan berkelanjutan. 7. Mengembangkan kelembagaan PKK sesuai dengan isu dan program strategis serta tantangan masyarakat DKI Jakarta

Dalam era tata kelola organisasi atau perusahaan, pengukuran kinerja perusahaan menjadi suatu hal yang penting bagi manajemen untuk melakukan evaluasi terhadap performa perusahaan selama ini dan untuk menyusun perencanaan tujuan di masa mendatang (Sadjiarto, Arja: 2000). Termasuk PKK sebagai sebuah organisasi atau lembaga kemasyarakatan yang menjalankan kegiatan dengan menggunakan sumber pendanaan publik atau dana pemerintah. Salah satu bentuk keterbukaan atau akuntabilitas terhadap pengelolaan PKK, dibutuhkan adanya pengukuran kinerja organisasi. Pengukuran kinerja yang dilakukan oleh suatu organisasi dapat meningkatkan manajemen strategis (Ahdiyana, Marita, 2019).

\section{METODE}

Untuk menyelesaikan permasalahan terhadap kondisi yang ada di masyarakat terutama organisasi kemasyarakatan PKK mengenai kurangnya pemahaman terhadap pentingnya pengukuran kinerja organisasi sebagai alat untuk meningkatkan kegiatan yang dilakukan dalam rangka mencapai tujuan organisasi, maka metode pelaksanaan yang dilakukan adalah dengan pemberian "Pelatihan Pengukuran Kinerja Organisasi”. Metode atau tahapan kegiatan yang dilakukan dimulai dari 1) menyusun rencana kerja (perencanaan) termasuk persiapan, 2) pelaksanaan kegiatan (pelatihan), 3) observasi dan evaluasi serta 4) refleksi.

Kegiatan perencanaan dan persiapan yang dilakukan yaitu :

1) Melakukan koordinasi dengan para pengurus PKK (Kota Jakarta Timur) untuk memperoleh persetujuan dan ijin serta jadwal pelaksanaan kegiatan pelatihan bagi para pengurus PKK Jakarta Timur.

2) Membuat materi pelatihan mengenai pengukuran kinerja organisasi. Untuk mempermudah peserta dalam memahami materi, selain penyampaian menggunakan slide dalam bentuk PPT, juga materi dalam bentuk word.

Kegiatan pelaksanaan terdiri dari :

1) Penyajian materi tentang Pengukuran Kinerja,

2) Penyajian materi tentang tata kelola, 3) Latihan mengukur kinerja dari kegiatan selama setahun terakhir.

Tahapan observasi dan evaluasi dilakukan dengan tujuan untuk mengetahui dampak atau perubahan pemahaman dari peserta pelatihan sebelum dan setelah pelatihan. Observasi dan evaluasi dalam bentuk kuesioner yang berisi beberapa pertanyaan untuk mengetahui pemahaman terhadap materi pelatihan yang telah diberikan kepada peserta. Selain kuesioner sebagai alat evaluasi, hasil latihan atau praktek yang diberikan juga menjadi salah satu bentuk observasi dan evaluasi. Secara umum hasil evaluasi memperlihatkan tingkat penerimaan dan pemahaman terhadap materi yang diberikan oleh pemateri sudah cukup baik.

Tahap terakhir yaitu refleksi yang dilakukan oleh tim pelaksana untuk mengetahui keefektifan pelaksanaan pelatihan tersebut dan dapat dijadikan dasar dalam menyelenggarakan pelatihan selanjutnya.

\section{HASIL DAN PEMBAHASAN}

Suatu organisasi didirikan memiliki tujuan, visi, misi dan harapan lainnya. Tujuan organisasi tersebut dicapai melalui kegiatankegiatan baik rutin maupun non-rutin sesuai 
41 Pelatihan Pengukuran Kinerja Organisasi Kemasyarakatan Dalam Meningkatkan Tatakelola PKK - Ludwina Harahap

DOI: https://doi.org/10.31004/abdidas.v1i2.11

dengan perencanaan yang telah disusun sebelumnya. Untuk memastikan apakah pelaksanaan kegiatan sudah sejalan dengan perencanaan maka diperlukan adanya penilaian atau pengukuran kinerja. Sayangnya, pengukuran kinerja sering diabaikan dan tidak dilakukan. PKK sebagai suatu organisasi kemasyarakatan yang memiliki tujuan mencapai kesejahteraan keluarga melalui pemberdayaan keluarga, sangat penting untuk menilai atau mengukur apakah kegiatan yang selama ini dilakukan sudah menuju ke arah tujuan tersebut. Sehingga pelatihan pengukuran kinerja kegiatan perlu diberikan kepada setiap pengurus PKK.

Pelatihan pengukuran kinerja yang dilaksanakan diikuti oleh pengurus Tim PKK Kecamatan Jakarta Timur yang berjumlah 110 orang. Pengurus Tim PKK Jakarta Timur yang ikut berasal dari unsur lembaga kemasyarakatan yang ada ditingkat Kelurahan yang terdiri dari 7 kelurahan yaitu Kelurahan Lubang Buaya, Kelurahan Ceger, Kelurahan Cipayung, Kelurahan Munjul, Kelurahan Pondok Rangon, Kelurahan Cilangkap, dan Kelurahan Setu. Materi pelatihan yang disampaikan yaitu metode atau cara pengukuran kinerja pelaksanaan kegiatan berbasis pengukuran Asosiasi Auditor Intern Pemerintah Indonesia (AAIPI) Tahun 2018-2022 (AAIP: 2019).

Metode pengukuran kinerja kegiatan yang diberikan meliputi :

1. Tertib Perencanaan: a. Menyusun rencana kerja, jadwal penyusunan rencana kerja, rencana anggaran dan rencana pengeluaran

2. Tertib Organisasi : a. Keterlibatan SDM Inti, jumlah tenaga SDM Pendukung, kompeternsi SDM Pendukung, pembagian tugas, struktur organisasi dan uraian tugas yang jelas

3. Tertib Administrasi : a. Melaksanakan sistem administrasi secara tertib, Memiliki sistem dalam penataan dokumen (pengarsipan), penyimpan dokumen dan arsip dengan baik

4. Tertib Sarana dan Prasarana : a. Kelengkapan peralatan kerja (komputer, laptop, peralatan khusus yang diperlukan, dan sebagainya), kelengkapan pendukung bagi pelaksanaan pekerjaan (filling cabinet, lemari, aplikasi tertentu, dan sebagainya)

5. Hasil kerja : a. Pelaksanaan kegiatan dilakukan sesuai prosedur yang berlaku yaitu NSPK (norma, standar, prosedur, dan kriteria), jadwal pelaksanaan pekerjaan maupun penggunaan anggaran, sesuai dengan perencanaan, hubungan kerja dengan pihak ketiga selalu dilengkapi dengan administrasi dan perjanjian kerja atau kontrak kerja, upaya perbaikan.
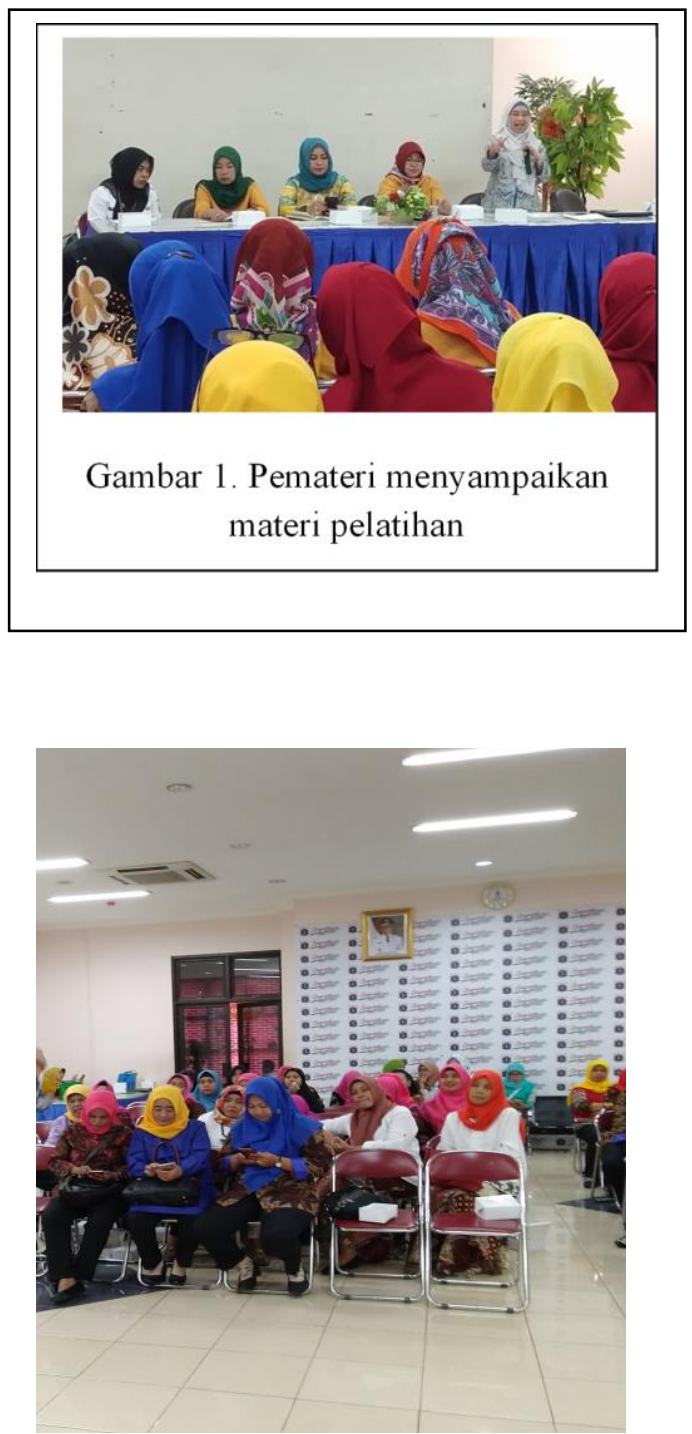

Gambar 2

Peserta Pelatihan Pengukuran Kinerja 
42 Pelatihan Pengukuran Kinerja Organisasi Kemasyarakatan Dalam Meningkatkan Tatakelola PKK - Ludwina Harahap

DOI: https://doi.org/10.31004/abdidas.v1i2.11

Selain materi mengenai pengukuran kinerja pelaksanaan kegiatan, peserta pelatihan diberi juga materi tentang tata kelola organisasi. Kedua materi yang disampaikan sangat berhubungan dan berkaitan langsung dengan kegiatan yang dilakukan oleh pengurus Tim PKK Kecamatan Cipayung Jakarta Timur. Tentunya dalam melaksanakan kegiatan yang sasarannya adalah masyarakat umum harus dilandasi dengan keterbukaan, adanya pertanggungjawaban dan akuntabilitas, serta keadilan.

Secara umum dan rata-rata peserta pelatihan memahami materi yang disampaikan, dengan ditandai dengan pertanyaan dan aktifnya peserta mengikuti rangkaian pelatihan mulai dari pembukaan yang disampaikan oleh Ketua PKK Kecamatan Jakarta Timur hingga berakhirnya pelatihan. Walaupun jumlah peserta yang bertanya secara persentase tidak lebih dari $10 \%$, namun terlihat adanya peningkatan pemahaman dari para peserta. Keterlibatan peserta dalam mengerjakan latihan menunjukkan adanya perubahan pemahaman mengenai pentingnya materi pengukuran kinerja bagi organisasinya.

\section{UCAPAN TERIMA KASIH}

Dengan diberikan ijin dan kerjasama sehingga terlaksananya pelatihan ini dari beberapa pihak, yaitu pengurus Tim PKK Kecamatan Cipayung Jakarta Timur, Universitas Trilogi dan beberapa pengurus kemasyarakatan di Kelurahan Ceger Jakarta Timur, kami menyampaikan banyak terima kasih dan berharap kerjasama yang sudah terbangun selama ini dapat terus dikembangkan.

\section{SIMPULAN}

Pelatihan pengukuran kinerja telah dilaksanakan dan diikuti oleh peserta yang antusias mendengarkan dan partisipatif selama pelatihan berlangsung. Peserta memperoleh pengetahuan dan pengalaman yang berarti dari keikutsertaan pelatihan tersebut. Materi pengukuran kinerja sangat dibutuhkan oleh pengurus PKK untuk mengevaluasi apakah selama ini kegiatan yang dilakukan sudah mengarah pada pencapaian tujuan visi dan misi.

Pelatihan ini disertai dengan praktek mengukur kinerja sehingga keterlibatan aktif dari peserta sangat besar dan hal inilah yang membuat peserta antusias dan mengharapkan dapat mempraktekkan ilmu yang diperoleh.

\section{DAFTAR PUSTAKA}

Wargadinata, Ella. 2017. Kualitas Pengukuran Kinerja Organisasi Publik. Bandung. Sosiohumaniora.

Ahdiyana, Marita. 2009. Memperkuat Manajemen Strategis Dengan Pengukuran Kinerja Dalam Organisasi Sektor Publik. Yogjakarta. Jurnal Ekonomi UMY.

Asosiasi Auditor Intern Pemerintah Indonesia (AAIPI). 2018. Pedoman Teknis : Penilaian Kinerja Pelaksanaan Kegiatan Tahun 2018 2022 .

Sadjiarto, Arja. Akuntabilitas Dan Pengukuran Kinerja Pemerintahan. Surabaya. Jurnal Akuntansi \& Keuangan Vol. 2, No. 2, Nopember 2000: 138 - 150 . 